\title{
KERATOKONUSAS IR JO SĄSAJOS SU ATOPINIU DERMATITU
}

\author{
Karolina Vaičiulytė ${ }^{1}$, Renata Vaičiuliené $\dot{e}^{1,2}$, Dalia Žaliūniene் $\dot{\mathbf{e}}^{1,2}$ \\ ${ }^{1}$ Lietuvos sveikatos mokslu universiteto Medicinos akademija, Medicinos fakultetas, \\ ${ }^{2}$ Lietuvos sveikatos mokslu universiteto ligoninė Kauno klinikos, Akiu ligų klinika
}

Raktažodžiai: keratokonusas, atopinis dermatitas, keratokonuso rizikos veiksniai.

\section{Santrauka}

Keratokonusas (KK) yra progresuojanti, neuždegiminè, dažniausiai abipusė akių liga, sukelianti netaisyklingą astigmatizmą ir regejjimo aštrumo sumažèjimą. Šiuos pokyčius lemia ragenos plonejjimas ir išsigaubimas. KK etiologija nèra aiški, tačiau manoma, kad tai yra daugiafaktorinè liga, apimanti genetinius, biocheminius ir aplinkos veiksnius. Vienas dažniausiai minimų veiksnių yra atopinès ligos. Manoma, kad atopija, ypač atopinis dermatitas (AD), yra susijęs su KK pasireiškimu ir progresavimu. Nustatyta, kad iki 40 proc. KK pacientų serga ir AD. Viena iš ligos išsivystymo priežasčiu yra ragenos trauma, kurią sukelia intensyvus akių trynimas. Reikia atkreipti dèmesị ị tai, kad akių trynimą skatina niežèjimas, o pastarajj - dažniausiai atopija. Svarbu suprasti AD ir KK sąsajas, kad galètume laiku nustatyti KK ir paskirti gydymą.

Straipsnyje apibendrinti naujausi duomenys apie KK ir jo sąsajas su AD.

Literatūros paieška buvo atlikta PubMed ir Google Scholar duomenų bazèse. Literatūros paieškai buvo naudojami raktiniai žodžiai, atitinkantys literatūros apžvalgos temą. Buvo atrinkti ne senesni nei penkerių metų straipsniai, publikuoti anglų kalba. Analizė atskleidè, kad KK ir AD sieja genetiniai bei biocheminiai ryšiai. Pagrindinès genų mutacijos, galimos esant šioms patologijoms, yra VSX1, SOD1, ZNF469 ir MIR184. Nustatėme, kad odoje ir ragenoje svarbu vaidmenị atlieka filagrinas. Šio baltymo geno mutacija pažeidžia odos ir ragenos epitelio barjerinę funkciją, dèl to prarandamas transepiderminis vanduo ir tai yra viena iš patogenezés grandžių abiejų ligų atvejais. KK sergančiu pacientų ašarose randamas didelis matricos metaloproteinazès (MMP) kiekis. İdomu tai, kad MMP randama ir odoje, kuris sukelia odos audinio struktūrinius pokyčius, sergant $\mathrm{AD}$. KK pa- žeistose ragenose pastebėtas pakitęs lizilo oksidazès aktyvumas, kuris gali lemti ragenos biomechaninio standumo sumažejjimą. Svarbu paminèti, kad lizilo oksidazès aktyvumo pakitimai minimi ir AD patogenezeje.

Sergantiems AD dèl padidejusios KK rizikos reikètų reguliariai lankytis pas akių gydytojus. Tai padètų anksčiau diagnozuoti ligą ir laiku paskirti jos progresavimą stabdantị gydymą, kuris sumažintų regèjimo praradimo riziką.

\section{Ivadas}

KK yra reta, neuždegiminès kilmės akių liga, sukelianti progresuojantį ragenos plonejjimą ir netaisyklingą išsigaubimą [1]. Dèl to laipsniškai didèja astigmatizmas, kuris blogina matymą [2]. KK dažniausiai pradeda vystytis brendimo metu ar jauniems darbingo amžiaus asmenims ir progresuoja iki trečio ar ketvirto dešimtmečio [3]. Naujausių studijų duomenimis nustatyta, kad vyrai šia liga serga dažniau, nei moterys [4]. KK paplitimas yra 50-2300 atvejų 100000 gyventojų [4]. Paplitimas skirtinguose pasaulio regionuose skiriasi, pavyzdžiui, Rusijoje jis siekia vos $0,3 / 100$ 000, o Centrineje Indijoje - 2300/100 000 [5]. Manoma, kad šį skirtumą lemia etniniai, genetiniai bei aplinkos veiksniai [5]. Tikslios KK išsivystymo priežastys kol kas nežinomos. Manoma, kad ligą sukelia genetinių ir aplinkos veiksnių sąveika [6]. Uždegiminių mediatorių, tokių kaip citokinai, ląstelių adhezijos molekulès ir matricos metaloproteinazès (toliau-MMP) ekspresija taip pat yra susijusi su ragenos destrukcija [7]. Literatūroje nurodoma, kad didelę dalị sergančiųjų KK vargina atopinès ligos [1]. 2018 m. Danijoje atliktoje didelès apimties populiacineje studijoje nustatyta, kad sergančiųų KK didesnè rizika susirgti alerginiu rinitu, astma ir atopiniu dermatitu (toliau - AD), nei sveikujų [8]. Studijų duomenimis, 13 proc. Amerikos gyventojų serga astma, 17 proc. - AD ir iki 16 proc. - alerginiu rinitu [9]. Pastaraisiais metais vis daugiau gaunama ịrodymų, kad AD gali sukelti pokyčius ne tik odoje. Epidemiologiniai tyrimai ịrodè, kad oftalmologinių komplikacijų paplitimas AD sergančiujų grupejje yra didesnis, lyginant su bendra populiacija 
$[10,11]$. Viena iš galimų oftalmologinių komplikacijų yra KK [11].

Darbo tikslas - apibendrinti naujausius duomenis apie $\mathrm{KK}$ ir jo sąsajas su AD.

\section{Tyrimo objektas ir metodika}

Mokslinėse duomenų bazèse rastos publikacijos. Literatūros paieška buvo atlikta PubMed ir Google Scholar duomenų bazėse. Literatūros paieškai buvo naudojami raktiniai žodžiai, atitinkantys apžvalgos temą. Apžvalgai buvo naudojami ne senesni nei penkerių metų straipsniai, publikuoti anglų kalba.

\section{Tyrimo rezultatai}

KK būdingas laipsniškas ragenos plonėjimas ir išsigaubimas, todèl laipsniškai didèja netaisyklingas astigmatizmas ir susiformuoja kūgio formos ragena. Šie pokyčiai ragenoje sukelia aukštos kartos aberacijas, kurios ženkliai blogina regejjimo aštrumą, gali kreivinti vaizdą, sukelti atspindžius ar net dvejinimąsi, žiūrint viena akimi [12]. Pavèluotai diagnozavus KK ir laiku nepaskyrus gydymo, matymas gali taip pablogèti, kad jokios kitos priemonės, išskyrus ragenos transplantaciją, jo nepagerina. Nustatyta, kad pacientai, sergantys KK, dažnai turi ir sisteminių ligų, tokių kaip AD. Epidemiologinių studijų duomenys parodè tiek KK, tiek AD paplitimo didejimo tendenciją [13-15]. Manoma, jog per pastaruosius dešimtmečius AD dažnis išaugo 2-3 kartus [16], todèl ši tema yra labai aktuali. Žinios apie KK ir jo sąsajas su kitomis dažniausiai pasitaikančiomis sisteminèmis ligomis yra reikalingos ne tik oftalmologams, bet ir kitu sričių gydytojams.

Tikslios KK priežastys kol kas nežinomos. Manoma, kad ligos išsivystymą lemia genetinių, biocheminių ir aplinkos veiksnių sąveika [17]. Visa tai sukelia molekulinius ir ląstelinius pokyčius ragenos epitelyje, Baumano sluoksnyje, stromoje bei Descemeto membranoje. Manoma, kad kolageno skaidulų disfunkcija yra svarbiausias veiksnys, lemiantis ragenos plonėjimą ir išsigaubimą [18]. 6 - 23,5 proc. KK sergančių asmenų yra teigiama šeiminè anamnezė [19]. Pirmos kartos giminaičiai turi 15-67 kartus didesni polinki sirgti šia liga [19]. Tikslus paveldèjimo modelis nèra žinomas [20]. Literatūroje nurodoma, kad MIR184, LOX, HGF, WNT10a, MPDZ-NF1B, ZNF469, IL1a, COL5A1, FOXO1, PDGFRA, BANP, IL1b, VSX1, SOD1 genų mutacijos turi itakos KK pasireiškimui $[16,17] .2018 \mathrm{~m}$. publikuotoje literatūros apžvalgoje išsamiai išanalizuotos KK lemiančios genų mutacijos bei tų pačių genų mutacijų sukeliamos kitos ligos. Remiantis studijomis, buvo nustatytos genų asociacijos tarp KK ir atopijos (COL8A2, SOD1), akių trynimo (DOCK9, FNDC3B, MIR184, RXRA, VSX1, MPDZ, PRDM5, RAB3GAP1, ZNF469, COL4A3, CRB1, COL8A2, CRX, HGF,
LOX, COL5A1, SOD1) bei alerginių ligų (RXRA, PRDM5, RAB3GAP1, ZNF469, COL1A1, SOD1) [21]. Iš aplinkos veiksnių, kurie gali lemti KK išsivystymą, išskiriami: akių trynimas, hormoniniai pokyčiai (paauglystė, něštumas) ir kontaktinių lęšiu nešiojimas [22]. Atopinès ligos, ypač AD literatūroje, nurodomos kaip vienas iš dažniausių gretutinių susirgimų, varginančių KK sergančius pacientus [1].

\section{Diskusija}

Atopinio dermatito ịtaka keratokonuso pasireiškimui.

AD yra plačiai paplitusi, lètinè ir progresuojanti odos liga. Ūmineje stadijoje jai būdinga eritema su edema ir pūslelèmis, o lètinèje - odos sustorèjimas (lichenifikacija) [23]. AD išsivysčiusiose šalyse paplitimas vaikams siekia 15-20 proc., o suaugusiems - 1-3 procentus [16]. AD diagnozuoti padeda J. Hanifin ir G. Rajka kriterijų, skirstomų i didžiuosius ir mažuosius, taikymas. Svarbu paminèti tai, kad KK priskiriamas prie mažujų kriterijų [24]. Manoma, kad atopija (ypač AD), kaip vienas iš rizikos veiksnių, gali būti susijęs tiek su KK pasireiškimu, tiek su ligos progresavimu [21,25].

AD serga 18-41 proc. sergančiujų KK [26]. Sergant AD, KK pasireiškimo rizika 10 kartų didesnè, lyginant su bendra populiacija [10]. Nustatyta, kad sergantiesiems AD, KK anksčiau išsivysto dominuojančios rankos pusèje [26]. 2020 m. J. Moon ir kiti autoriai paskelbė studiją, kurioje buvo ieškoma sąsajų tarp KK ir kitų sisteminių ligų. I studiją buvo ịtraukta 1025340 pacientų. Tyrimo rezultatai parodè statistiškai reikšmingas sąsajas tarp KK ir alerginio rinito, astmos bei AD [2]. M. Shajari su kolegomis studijos rezultatai atskleide, kad pacientai, sergantys KK ir atopiniu sindromu, buvo reikšmingai jaunesni, nei tie, kurie sirgo vien tik keratokonusu. Autoriai priëjo prie išvados, kad atopinis sindromas gali sukelti ankstyvesnį KK pasireiškimą [1]. Literatūroje nurodoma, kad AD sergantys pacientai yra linkę ị alergini konjunktyvitą, vernalinį keratokonjunktyvitą bei atopinį keratokonjunktyvitą.

Galimą akių alergijos ir KK sąsają pirmasis aprašè H. Hilgartner 1937 metais [25]. Studijose įrodyta, kad tarp KK sergančių pacientų didesnis vernalinio keratokonjunktyvito, alerginio konjunktyvito, astmos ir AD paplitimas [27]. R. Lapid-Gortzak su bendraautoriais aprašè tyrimą, kuriame nustate, kad tarp vaikų, sergančių vernaliniu keratokonjunktyvitu, reikšmingai dažniau randama ragenų topografijos pakitimų, lyginant su bendra populiacija [28]. S. Emre ir kolegų studijos rezultatai parodè, kad vaikų, sergančių vernaliniu keratokonjunktyvitu, centrinès ragenos storis buvo gerokai mažesnis nei vaikų, neturinčių vernalinio keratokonjunktyvito [28]. Panašius rezultatus atskleidè ir V. Kaya ir kt. atliktas tyrimas. Tyrejjai nustatė, kad pacientų, sergančių $\mathrm{KK}$ ir turinčių atopini sindromą, centrinè ragenos dalis yra plonesnè, lyginant su pacientais, kurie neturi atopijos [1]. 
Tai i̇rodo, kad KK eiga agresyvesnè pacientams, sergantiems alerginèmis ligomis. Manoma, kad KK ir alerginio konjunktyvito, vernalinio keratokonjunktyvito ir (ar) AD sąsajos galimos dèl dažno ir intensyvaus akių ir odos aplink akis trynimo [26,27].

Pasikartojanti ragenos trauma dèl intensyvaus akių trynimo veda prie stromos rekonstrukcijos ir keratocitų apoptozès, atsirandančios dèl MMP 1 ir 13, interleukinų [toliau - IL] 1 ir naviko nekrozès faktoriaus [toliau - TNF] išsiskyrimo [29]. A. Bawazer ir kiti autoriai teigia, kad akių trynimą lemia akių niežèjimas, kurị sukelia atopija [1], tačiau nustatyta, kad sergantys KK asmenys, net ir neturintys atopijos, skundžiasi akių niežuliu ir trina akis [29], todèl pacientams, sergantiems KK, kurie trina akis (net ir neturintiems jokių alerginių ligų) ar linkę i atopiją, sirgusiems alerginèmis ligomis, skiriami vietiniai vaistai nuo alergijos (antihistamininiai, nuo uždegimo, putliujų ląstelių stabilizatoriai).

Atopinio dermatito ir keratokonuso sąsajos. AD pasireiškimą lemia genetiniai (pvz., filagrino geno (FLG) mutacijos) ir aplinkos veiksniai (klimatas, dieta, žindymas) [16]. Pagrindinis sutrikusios odos barjerinès funkcijos rizikos veiksnys yra FLG mutacija. Šis genas koduoja odos struktūrinius baltymus [30]. Dažniausiai pasitaikančios FLG mutacijos yra R501X ir 2282del4, paveikiančios iki 10 proc. Europos gyventojų [30]. Dèl šio geno mutacijos susilpnėja odos barjeras ir prarandamas transepiderminis vanduo, o tai lemia AD išsivystymą [23]. Nustatyta, kad filagrino yra ir ragenos epitelyje, kur jis palaiko ragenos epitelio barjerinę funkciją [30]. Maždaug 30 proc. AD sergančių pacientų yra FLG mutacijų nešiotojai, todèl jie turi didelę KK išsivystymo riziką [30]. C. Droitcourt ir kt. atliko tyrimą, kurio rezultatai atskleide, kad asmenys, turintys FLG mutaciją, sirgo sunkesne KK forma ir jiems prireikè agresyvesnio gydymo, nei pacientams, neturintiems FLG mutacijos [23].

Nors KK laikoma neuždegimine liga, tačiau pacientų ašarose buvo rastas padidèjęs kai kurių uždegiminių molekulių, iskaitant IL ir TNF, kiekis. Keli tyrimai parode, kad IL ir TNF reguliuoja MMP raišką, taip sukeldami lètinị uždegimą. Ragenos plonejjimas ir išsigaubimas yra pagrindiniai KK požymiai, kurie priskiriami ragenos kolageno kiekio sumažèjimui dẻl tarpląstelinès matricos irimo. Šiuos pakitimus gali lemti būtent per didelis MMP išsiskyrimas, kuris gali būti kaip viena iš svarbesnių grandžių KK patogenezèje. Verta paminèti, kad IL-1 citokinų šeimos nariai, tarpininkaujantys igimtam imuniniam atsakui, vaidina svarbų patofiziologini vaidmeni $A D$ atvejais [31]. MMP-2 ir MMP-9 veikia kaip tarpląstelinę matricą ardantys fermentai ir taip pat yra susiję ir su odos audinio struktūriniais pokyčiais, sergant $\mathrm{AD}$ [31].

Sergančių KK pacientų ragenose aptiktas pakitęs lizilo oksidazės aktyvumas. Lizilo oksidaze yra fermentas, katalizuojantis jungtis tarp kolageno ir elastino skaidulų. Pakitęs lizilo oksidazès aktyvumas silpnina minètas jungtis, o tai gali sukelti ragenos biomechaninio standumo mažèjimą [32]. Šio fermento randama odos epidermyje, o jo aktyvumo pakitimai taip pat minimi AD patogenezèje [33].

Dermatologų ir oftalmologụ bendradarbiavimo svarba. KK yra progresuojanti būklè, galinti sukelti negrịžtamą regèjimo praradimą, todèl būtina atkreipti dèmesị i sergančiujų $\mathrm{AD}$ oftalmologinius nusiskundimus ir siųsti detaliam akių ištyrimui $[23,26]$. Asmenims, sergantiems $A D$, ypač turintiems šeiminę KK anamnezę, turètų būti patarta reguliariai lankytis pas akių ligų gydytojus. Akių patikra turètų būti dažnesnè pirmaisiais gyvenimo dešimtmečiais, kai KK progresavimas aktyviausias [34]. Nepaisant galimo regėjimo praradimo pavojaus, reguliarus oftalmologinis ištyrimas nėra ịprastas daugumai sergančiujų AD. Dermatologai turètų atkreipti dèmesị ị galimas AD gretutines akių ligas, taip užtikrinant ankstyvą KK diagnozę ir laiku pradètą gydymą [26].

Ankstyva KK diagnostika yra labai svarbi, nes vèlai diagnozavus ligą, blogesnè gydymo baigtis, pacientai prasčiau mato, todèl nukenčia jų gyvenimo kokybė [35]. Anksti nustačius progresuojanti KK, galima taikyti gydymą, tokị kaip ragenos sutvirtinimo procedūra (RSP), stabdantị ligos progresavimą [35]. Tai minimaliai invazyvi procedūra, kurios metu naudojamas riboflavinas ir ultravioletine A (UVA) šviesa [36]. Procedūros metu apšvitinus UVA spinduliais i̇sotintą riboflavinu rageną, ịvyksta biocheminè reakcija, dèl to padideja ragenos biomechaninis standumas (sustabdomas ligos progresavimas) ir sumažèja centrinès ragenos dalies gaubtumas (šiek tiek gali pagerèti matymas) [36-38]. Ankstyvoji KK diagnostika turi reikšmingą socioekonominę naudą. D. Godefrooij ir kt. aprašè tyrimą, kurio metu nustatè, kad Nyderlanduose pradejjus taikyti RSP, 25 proc. sumažėjo ragenos transplantacijų skaičius [39].

Lietuvos sveikatos mokslų universiteto ligoninèje Kauno klinikose (toliau - LSMUL KK) nuo 2016 m. šis inovatyvus gydymo metodas prieinamas visiems KK sergantiems pacientams. 2019 m. tarptautinèje konferencijoje LSMUL KK Akių ligų klinikos mokslininkai pristate pacientu, kuriems dèl progresuojančio KK buvo taikyta RSP, gydymo baigtis. Duomenys atskleide, kad šis gydymo metodas pacientams efektyviai sustabdè ligos progresavimą ir pagerino matymą [40].

\section{Išvados}

AD yra rizikos veiksnys KK išsivystymui jaunesniame amžiuje. Ši liga siejama su agresyvesne KK eiga. Asmenys, sergantys $\mathrm{AD}$, turètų būti reguliariai tikrinami oftalmologų dèl padidèjusios KK rizikos.

\section{Literatūra}

1. Shajari M, Eberhardt E, Müller M, Al Khateeb G, Friderich S, 
Remy M, et al. Effects of atopic syndrome on keratoconus. Cornea 2016;35(11):1416-20. https://doi.org/10.1097/ICO.0000000000000935

2. Moon JY, Lee J, Park YH, Park E-C, Lee SH. Incidence of keratoconus and its association with systemic comorbid conditions: a nationwide cohort study from South Korea. J Ophthalmol 2020;2020:1-6. https://doi.org/10.1155/2020/3493614

3. Martínez-Abad A, Piñero DP. New perspectives on the detection and progression of keratoconus. J Cataract Refract Surg 2017;43(9):1213-27. https://doi.org/10.1016/j.jcrs.2017.07.021

4. Woodward MA, Blachley TS, Stein JD. The association between sociodemographic factors, common systemic diseases, and keratoconus an analysis of a nationwide heath care claims database. Ophthalmology 2016;123(3):457-465.e2. https://doi.org/10.1016/j.ophtha.2015.10.035

5. El-Khoury S, Abdelmassih Y, Hamade A, Slim E, Cherfan CG, Chelala E, et al. Pediatric keratoconus in a tertiary referral center: incidence, presentation, risk factors, and treatment. J Refract Surg 2016;32(8):534-41. https://doi.org/10.3928/1081597X-20160513-01

6. Magalhaes OA, Fujihara FMF, de Brittes EBN, Tavares RN. Keratoconus development risk factors: a contralateral eye study. J Eu Cornea 2020;7:1-3.

https://doi.org/10.1016/j.xjec.2020.02.003

7. Galvis V, Sherwin T, Tello A, Merayo J, Barrera R, Acera A. Keratoconus: an inflammatory disorder? Eye 2015;29(7):843-59. https://doi.org/10.1038/eye.2015.63

8. Bak-Nielsen S, Ramlau-Hansen CH, Ivarsen A, Plana-Ripoll $\mathrm{O}$, Hjortdal J. A nationwide population-based study of social demographic factors, associated diseases and mortality of keratoconus patients in Denmark from 1977 to 2015. Acta Ophthalmol 2019;97(5):497-504. https://doi.org/10.1111/aos.13961

9. Merdler I, Hassidim A, Sorkin N, Shapira S, Gronovich Y, Korach Z. Keratoconus and allergic diseases among Israeli adolescents between 2005 and 2013. Cornea 2015;34(5):525-9. https://doi.org/10.1097/ICO.0000000000000416

10. Thyssen JP, Toft PB, Halling-Overgaard AS, Gislason GH, Skov L, Egeberg A. Incidence, prevalence, and risk of selected ocular disease in adults with atopic dermatitis. J Am Acad Dermatol 2017;77(2):280-286.e1. http://dx.doi.org/10.1016/j. jaad.2017.03.003 https://doi.org/10.1016/j.jaad.2017.03.003

11. Govind K, Whang K, Khanna R, Scott AW, Kwatra SG. Atopic dermatitis is associated with increased prevalence of multiple ocular comorbidities. J Allergy Clin Immunol Pract 2019; 7(1):298-9. https://doi.org/10.1016/j.jaip.2018.10.009

12. Karolak JA, Gajecka M. Genomic strategies to understand causes of keratoconus. Mol Genet Genomics 2017;292(2):251-69. https://doi.org/10.1007/s00438-016-1283-z

13. Godefrooij DA, de Wit GA, Uiterwaal CS, Imhof SM, Wisse RPL. Age specific incidence and prevalence of keratoconus: a nationwide registration study. Am J Ophthalmol 2017;175:16972. http://dx.doi.org/10.1016/j.ajo.2016.12.015

https://doi.org/10.1016/j.ajo.2016.12.015

14. Kowalska-Olędzka E, Czarnecka M, Baran A. Epidemiology of atopic dermatitis in Europe. J Drug Assess 2019;8(1):126-8. https://doi.org/10.1080/21556660.2019.1619570

15. Giovannini M, Geat D, Barlocco G, Pertile R, Mori F, Filippeschi C, et al. A caregiver-reported global severity assessment in pediatric atopic eczema: the Comano score. Ital J Pediatr 2020;46(1):4-8 https://doi.org/10.1186/s13052-020-0805-9

16. Nutten S. Atopic dermatitis: global epidemiology and risk factors. Ann Nutr Metab 2015;66:8-16. https://doi.org/10.1159/000370220

17. Downie LE, Lindsay RG. Contact lens management of keratoconus. Clin Exp Optom 2015;98(4):299-311. https://doi.org/10.1111/cxo.12300

18. Mas Tur V, MacGregor C, Jayaswal R, O'Brart D, Maycock N. A review of keratoconus: diagnosis, pathophysiology, and genetics. Surv Ophthalmol 2017;62(6):770-83. https://doi.org/10.1016/j.survophthal.2017.06.009

19. Khaled ML, Helwa I, Drewry M, Seremwe M, Estes A, Liu Y. Molecular and histopathological changes associated with keratoconus. Biomed Res Int 2017;2017. https://doi.org/10.1155/2017/7803029

20. Gordon-Shaag A, Millodot M, Shneor E, Liu Y. The genetic and environmental factors for keratoconus. Biomed Res Int 2015;2015:24-32. https://doi.org/10.1155/2015/795738

21. Loukovitis E, Sfakianakis K, Syrmakesi P, Tsotridou E, Orfanidou M, Bakaloudi DR, et al. Genetic aspects of keratoconus: a literature review exploring potential genetic contributions and possible genetic relationships with comorbidities. Ophthalmol Ther 2018;7(2):263-92. https://doi.org/10.1007/s40123-018-0144-8

22. Valgaeren H, Koppen C, Van Camp G. A new perspective on the genetics of keratoconus: why have we not been more successful? Ophthalmic Genet 2018;39(2):158-74. https://doi.org/10.1080/13816810.2017.1393831

23. Pietruszyńska M, Zawadzka-Krajewska A, Duda P, Rogowska M, Grabska-Liberek I, Kulus M. Ophthalmic manifestations of atopic dermatitis. Adv Dermatology Allergol 2018;1-6.

24. Silverberg NB. Typical and atypical clinical appearance of atopic dermatitis. Clin Dermatol 2017;35(4):354-9. https://doi.org/10.1016/j.clindermatol.2017.03.007

25. Mazzotta C, Traversi C, Mellace P, Bagaglia SA, Zuccarini S, Mencucci R, et al. Keratoconus progression in patients with allergy and elevated surface matrix metalloproteinase 9 pointof-care test. Eye Contact Lens 2018;44(0):S48-53. https://doi.org/10.1097/ICL.0000000000000432

26. Beck KM, Seitzman GD, Yang EJ, Sanchez IM, Liao W. Ocular co-morbidities of atopic dermatitis. Am J Clin Dermatol 2019;20(6):797-805. https://doi.org/10.1007/s40257-019-00455-5 
27. Naderan M, Rajabi MT, Zarrinbakhsh P, Bakhshi A. Effect of allergic diseases on keratoconus severity. Ocul Immunol Inflamm 2017;25(3):418-23. https://doi.org/10.3109/09273948.2016.1145697

28. Solomon A. Corneal complications of vernal keratoconjunctivitis. Curr Opin Allergy Clin Immunol 2015;15(5):489-94. https://doi.org/10.1097/ACI.0000000000000202

29. Barbara A. Controversies in the management of keratoconus. Controv Manag Keratoconus 2018;1-397. https://doi.org/10.1007/978-3-319-98032-4_1

30. Juul-Dam M, Sejersen H, Vestergaard C, Deleuran M, Hjortdal $\mathrm{J}$. The impact of filaggrin genotype and atopic dermatitis on risk and severity of keratoconus. J Eu Cornea 2020;7:4-7. https://doi.org/10.1016/j.xjec.2020.02.001

31. Chang Y-S, Weng S-F, Wang J-J, Tseng S-H, Wang J-Y, Jan $\mathrm{H}-\mathrm{Y}$, et al. Association between keratoconus and the risk of adolescent or adult onset atopic dermatitis. Allergy 2020;0-2. https://doi.org/10.1111/all.14320

32. Robati RM, Einollahi B, Einollahi H, Younespour S, Fadaifard S. Skin biophysical characteristics in patients with keratoconus: a controlled study. Scientifica [Cairo] 2016;2016. https://doi.org/10.1155/2016/6789081

33. Ghosh D, Ding L, Sivaprasad U, Geh E, Biagini Myers J, Bernstein JA, et al. Multiple transcriptome data analysis reveals biologically relevant atopic dermatitis signature genes and pathways. PLoS One 2016;10(12):e0144316. https://doi.org/10.1371/journal.pone. 0144316

34. Hsu JI, Pflugfelder SC, Kim SJ. Ocular complications of atopic dermatitis. Cutis 2019;104(3):189-93.

35. Masiwa LE, Moodley V. A review of corneal imaging methods for the early diagnosis of pre-clinical keratoconus. J Optom 2020;1-7. https://doi.org/10.1016/j.optom.2019.11.001

36. Zhu AY, Jun AS, Soiberman US. Combined protocols for corneal collagen cross-linking with photorefractive surgery for refractive management of keratoconus: update on techniques and review of literature. Ophthalmol Ther 2019;8(s1):15-31. https://doi.org/10.1007/s40123-019-00210-3

37. Shetty R, Kaweri L, Pahuja N, Nagaraja H, Wadia K, Jayadev $\mathrm{C}$, et al. Current review and a simplified "five-point management algorithm" for keratoconus. IJO Ophthalmic Perspective 2015;63(1):46-53. https://doi.org/10.4103/0301-4738.151468

38. Hashemi H, Alvani A, Seyedian MA, Yaseri M, et al. Appropriate sequence of combined intracorneal ring implantation and corneal collagen cross-linking in keratoconus: a systematic review and meta-analysis. Cornes 2018;37(12):1601-7. https://doi.org/10.1097/ICO.0000000000001740

39. Godefrooij DA, Gans R, Imhof SM, Wisse RPL. Nationwide reduction in the number of corneal transplantations for keratoconus following the implementation of cross-linking. Acta Ophthalmol 2016;94(7):675-8. https://doi.org/10.1111/aos.13095

40. Forum XVI, Balticum O. Euretina Vilnius, 2019.

\section{THE INTERFACE OF KERATOCONUS} WITH ATOPIC DERMATITIS

K. Vaičiulytė, R. Vaičiulienė, D. Žaliūnienė

Keywords: keratoconus, atopic dermatitis, risk factors for keratoconus.

Summary

Keratoconus $(\mathrm{KC})$ is a progressive, non-inflammatory, mostly reciprocal eye disease that causes irregular astigmatism and decreased visual acuity. These changes are affected by corneal thinning and convexity. The etiology of $\mathrm{KC}$ is not clear, but it is thought to be a multifactorial disease involving genetic, biochemical, and environmental factors. One of the most frequently mentioned factors is atopic disease. Atopia, especially AD, is believed to be associated with the manifestation and progression of KC. Up to $40 \%$ of patients with $\mathrm{KC}$ have been found to have $\mathrm{AD}$. One of the mechanisms of disease development is corneal trauma caused by intense rubbing of the eyes. It should be noted that eyes rubbing is caused by itching, and the latter is usually caused by atopy. It is important to understand the associations between $\mathrm{AD}$ and $\mathrm{KC}$, so that we can identify $\mathrm{KC}$ in a timely manner and prescribe timely treatment.

Aim. The aim of this review was to summarize recent data on $\mathrm{KC}$ and its associations with $\mathrm{AD}$.

Materials and Methods. Publications found in scientific databases. The literature search was performed on PubMed and Google Scholar databases. Keywords relevant to the topic of the literature review were used to search the literature. For the review, articles not older than 5 years were used and published in English.

Results. After reviewing the literature, we found that $\mathrm{KC}$ and $\mathrm{AD}$ are associated by genetic and biochemical links. The main gene mutations that are possible in these pathologies are VSX1, SOD1, ZNF469 and MIR184. We also found that filagrin plays an important role in the skin and cornea. Mutation in the gene of this protein impairs the barrier function of the skin and corneal epithelium, resulting in the loss of transepidermal water and is one of the links in the pathogenesis of both diseases. High levels of matrix metalloproteinase (MMP) are found in the tears of patients with KC. Interestingly, MMP is also found in the skin, which causes structural changes in skin tissue in AD. Also, changes in lysyl oxidase activity have been observed in the corneas damaged by $\mathrm{KC}$, which may lead to a decrease in the biomechanical stiffness of the cornea. It is important to note that changes in lysyl oxidase activity are also mentioned in the pathogenesis of AD.

Conclusions. Patients with AD should have regular visits to ophthalmologists due to an increased risk of developing KC. This would help to diagnose the disease earlier and prescribe timely treatment to stop the progression of the disease, which would reduce the risk of vision loss.

Correspondence to: vaiciulyte.karolina@gmail.com

Gauta 2020-05-13 